STUDI

FRANCESI

\section{Studi Francesi}

Rivista quadrimestrale fondata da Franco Simone

143 (XLVIII | II) | 2004

Varia - fasc. II - maggio-agosto 2004

\title{
Jean Garapon, Amateurisme littéraire et vérité sur soi de Marguerite de Valois au Cardinal de Retz
}

\section{Cecilia Rizza}

\section{(2) OpenEdition}

1 Journals

\section{Edizione digitale}

URL: https://journals.openedition.org/studifrancesi/39273

DOI: 10.4000/studifrancesi.39273

ISSN: 2421-5856

\section{Editore}

Rosenberg \& Sellier

\section{Edizione cartacea}

Data di pubblicazione: 1 décembre 2004

Paginazione: 360

ISSN: 0039-2944

\section{Notizia bibliografica digitale}

Cecilia Rizza, «Jean Garapon, Amateurisme littéraire et vérité sur soi de Marguerite de Valois au Cardinal de Retz», Studi Francesi [Online], 143 (XLVIII | II) | 2004, online dal 30 novembre 2015, consultato il 19 mai 2021. URL: http://journals.openedition.org/studifrancesi/39273 ; DOI: https://doi.org/10.4000/ studifrancesi.39273

Questo documento è stato generato automaticamente il 19 mai 2021.

\section{(c)}

Studi Francesi è distribuita con Licenza Creative Commons Attribuzione - Non commerciale - Non opere derivate 4.0 Internazionale. 


\title{
Jean Garapon, Amateurisme littéraire et vérité sur soi de Marguerite de Valois au Cardinal de Retz
}

\author{
Cecilia Rizza
}

\section{NOTIZIA}

JEAN GARAPON, Amateurisme littéraire et vérité sur soi de Marguerite de Valois au Cardinal de Retz, «Revue d'histoire littéraire de la France», 2003, n. 2, pp. 275-185.

1 Comune a tutti i memorialisti del XVII secolo è la volontà di dare ai loro scritti autobiografici carattere di verità. Sarebbe cioè estranea alle loro intenzioni la volontà di fare opera letteraria, trattandosi di testimonianze redatte per se stessi o riservate ad un numero limitato e scelto di eventuali lettori. L'A. sottolinea nelle memorie di Margherita di Valois la sobrietà dello stile, la discontinuità del racconto, la teatralità di alcune scene; ciò non significa che la scrittrice non tenga presenti alcuni importanti esempi letterari quali le biografie di Plutarco o gli Annales di Tacito nonché una ben nota tradizione umanistica. Più consapevole della forza della propria tradizione culturale, più visibilmente impegnato nelle vicende politiche di cui è stato protagonista. il Retz mira a dare ai posteri un'immagine di sé cui subordina la verità storica. Diverso è dunque il rapporto dei due autori con la letteratura perché il presunto amateurisme rivela in ciascuno, insieme alla presenza di una verità personale, il rapporto con una cultura della quale sono inevitabilmente e profondamente debitori. 